\title{
Problems of energy-efficient construction in Russia
}

\author{
Liubov Shilova ${ }^{1}$, Leonid Shilov ${ }^{1 \mathrm{a}}$, Andrey Atamanov ${ }^{1}$, and Ilya Ermakov ${ }^{1}$ \\ ${ }^{1}$ National Research Moscow State University of Civil Engineering, 129337, Moscow, Russia
}

\begin{abstract}
The article considers the world practice in the field of energysaving construction technologies as well as the present-day situation in Russia. Also the authors consider problems associated with the growth of energy consumption and electricity generation, raise questions concerning the environmental problems of energy production. The recommendations on the reduction of energy consumption are given.
\end{abstract}

The electricity production is a complicated labour-consuming process depending on many factors from world economic market situations to the power resources limitedness and negative effects on the environment. Therefore, in addition to the fossil fuel output, it is also necessary to pay attention to the measures on reduction of energy consumption and on the efficiency of its use.

The energy consumption in the Russian Federation is more than 3 times as large as that in the West European countries; the RF economy is one of the most energy-consuming economies in the world [1]. In this connection, the RF Government set in 2008 a rather ambitions goal: to reduce the energy consumption by not less than $40 \%$ (in comparison with 2007) by 2020. This goal has been formulated in the RF President Decree No. 889 dated 04.07.2008 "About some measures on improvement of energy efficiency and environmental safety of the RF economy"; the aforesaid decree has been put into the basis of the Federal Law No. $261 \mathrm{FZ}$ (dated 23.11.2009, wording from 13.07.2015) "About the energy-saving and the improvement of energy efficiency as well as the introduction of changes into particular legislative documents in the RF".

In this document, the problem of reduction of energy consumption in construction industry and housing-and-communal services is considered to be one of the most important problems as the hot-water heating and hot-water supply require about $1 / 3$ of the energy consumed, which may be reduced through the construction of energy-efficient buildings. The construction dynamics for residential buildings within the period from 1990 till 2014, presented in Figure 1, testifies to the fact that, since 2000, the residential floor areas became much larger, which also led to greater energy consumption.

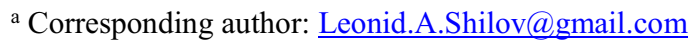




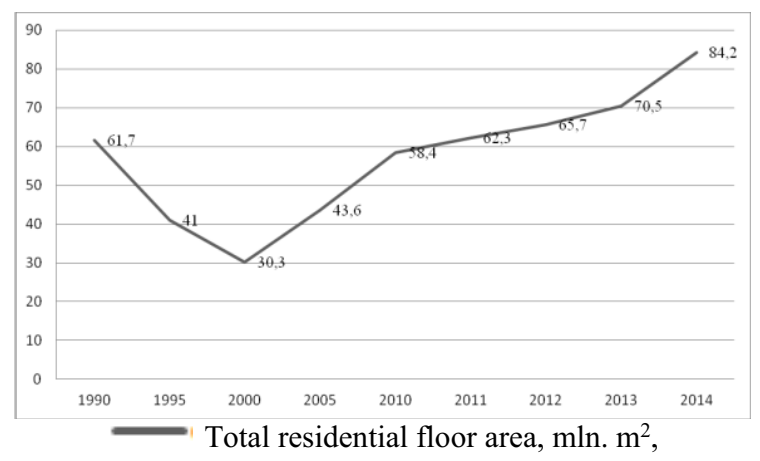

Fig. 1. The total residential floor area, $\mathrm{mln} . \mathrm{m}^{2}$, of buildings introduced into maintenance within the period from 1990 to 2014

The energy efficiency requirements for buildings and structures as well as the requirements to the determination of the energy efficiency categories are approved by the RF Government Decree No. 18 dated 25.01.2011.

The energy efficiency requirements for the buildings and structures are also included into the Federal Law No.384-FZ dated 30.12.2009 (wording from 02.07.2013) "Engineering regulations concerning the safety of buildings and structures".

The question of energy-saving in construction was raised as early as in 1970s in connection with the concept of "sustainable development". The first energy-efficient buildings (the structures with low energy consumption or no heating facilities [2-4]) appeared in 1974, after the world energy crisis.

The first energy-efficient 7-storey office building with the total floor area of $16350 \mathrm{~m}^{2}$ has been designed by the architects $\mathrm{N}$. Isaak and E. Isaak in the USA. The optimum planning and air flow distribution reduced the energy consumption for the ventilation system. The energy spent on the air cooling or air heating was also reduced due to the recuperating heat exchangers. The electric energy consumption was reduced due to the control over the illumination devices: the electric light intensity in the building depends on the natural light level [5].

In 1979, in Finland, the second energy-efficient building (ECONO-house) was put into service; the building was designed and erected under the supervision of the architect H. Kautonen. The structure provides for a rational use of the internal volume: the fencing structure surface is minimized and so the heat loss is reduced.

The trend used in the first energy-efficient building in the USA develops successfully even in the Northern countries, and the second trend, put into the basis of the Finnish energy-efficient house, started a new tendency in the construction industry called "Intellectual buildings".

In 1977, new energy-saving construction norms and standards were taken at the State level in Denmark (Danish BR77 Standard); and in 1980, those were taken in Sweden (SBN80, Svensk Bygg Norm). By 1988, Sweden reduced the heat losses in residential buildings by almost $50 \%$. Denmark consumed the heat energy in residential buildings in 1985 by $28 \%$ less in comparison with that in 1972.

Up to now, the Danish and Swedish energy consumption standards in construction are considered the most strict ones in the world.

In 1980s, the joint Swedish and German efforts created the concept of a passive building (Passivhaus), which has a continuous building shell with an improved heat insulation and the thermal conductivity of less than $0.15 \mathrm{~W} / \mathrm{m}^{2} \cdot \mathrm{K}[6]$. 
The founder of the concept is doctor Feist, who calculated the energy balance of the buildings until he reached the parameters of the building which didn't require any special heating system.

In accordance with this concept, the first experimental Passivhaus-prototype was erected in Germany in 1991; a successful building service led to a series construction of such buildings: there were more than 7000 passive buildings in Germany by 2007 .

The next stage of development of "passive buildings" is considered to be an "active building" which must provide the electric energy and hot water for itself. Nowadays typical equipment in the active building includes a solar collector for the production of hot water, a solar power station on the roof and a heat pump transforming the low potential heat of the earth or the domestic sewage into the hot water. Thus, a real "passive building" includes a power station as well.

The first active building has been erected in Denmark; first, it consumes not much energy (like a passive building); second, it produces the energy and can pass it to the central network, which is paid in several European countries.

The highest stage of the development of energy-efficient buildings is the "Sustainable building" construction. A sustainable building is a building with a comfortable microclimate in its rooms, where the energy of the nature is used to the greatest extent and the energy elements of the building as a whole are optimized.

Nowadays, the best energy efficient building is an office building in Norway which produces more energy $(200000 \mathrm{~kW} \cdot \mathrm{h})$ than consumes. This unique "Kjørbo" building has the total floor area of $2600 \mathrm{~m}^{2}$; it is situated at the Sandwik embankment (suburb of Oslo); after the global reconstruction it requires about $100000 \mathrm{~kW} \cdot \mathrm{h} /$ year. The electric energy is generated through the solar panels. The tight joints of walls, floors, windows as well as a proper heat insulation provided for the minimum heat losses, and the façade facing considerably reduced the heating consumption of the building in summer [7].

In Russia we also have some examples of energy-efficient construction: two buildings are erected in Sevastopol for the purpose of the study of possible recommendations on the improvement of energy efficiency of buildings.

The first building is an administrative building, where some energy-saving measures are suggested: the walls are filled with aerated concrete blocks or with a local porous natural material (shell rock; its thermal conductivity is close to that of the aerated concrete). The glazing area of the Southern façade considerably exceeds that of the Northern facade; the glazing includes the energy-saving windows, etc.

The second building is a residential one; the same measures were taken there as well. In addition to that, the building contains a hanging facade with a ventilated gap; there are some mineral wool panels in the gap. Both the orientation of the building and the landscape were taken into consideration in the process of construction of the building.

A two-storey energy-efficient building is being under construction in Moscow Region. It is supposed that the building will consume not more than $45 \mathrm{~kW} \cdot \mathrm{h} /\left(\mathrm{m}^{2} \cdot\right.$ year $)$ due to the use of modern mineral wool insulation, the energy-saving multiple glass units, the air recuperation system and the heat pump.

In average, the heat energy consumption in low buildings equals 150 to $300 \mathrm{~kW} \cdot \mathrm{h} /\left(\mathrm{m}^{2} \cdot\right.$ year) (the normative value is 95 to $195 \mathrm{~kW} \cdot \mathrm{h} /\left(\mathrm{m}^{2} \cdot\right.$ year $\left.)\right)$.

In Tomsk, a block of flats has been included into the highest energy-efficiency category " $A$ " due to a complex introduction of energy-saving technologies.

The structure of energy consumption for a block of flats before the reconstruction and after that is given in Table 1 [8]. 
Table 1. Main service parameters of a residential building: before the reconstruction and after that.

\begin{tabular}{|c|l|c|c|}
\hline \multirow{2}{*}{ № } & \multicolumn{1}{|c|}{ Energy resource } & \multicolumn{2}{c|}{ Basis month energy consumption } \\
\cline { 3 - 4 } & & January, 2012 & January, 2014 \\
\hline 1. & Electric energy, $\mathrm{kW} \cdot \mathrm{h}$ & 2509,00 & 2714,777 \\
\hline 2. & Heat energy, Gcal & 53,57 & 23,66 \\
\hline 3. & Cold water, $\mathrm{m}^{3}$ & 215,76 & 208,082 \\
\hline 4. & Hot water, $\mathrm{m}^{3}$ & 156,24 & 116,816 \\
\hline 5. & Sewage, $\mathrm{m}^{3}$ & 372 & 324,898 \\
\hline
\end{tabular}

The plan of capital repair works may include energy-saving engineering solutions directed at a considerable improvement of the energy efficiency category of the building.

Since 2008, Moscow State University of Civil Engineering has an Energy Efficiency Situation Centre (EESC) created on the basis of the Research-and-Education Centre for Information Systems and Intellectual Automation in Construction.

Now the EESC carries out the energy-efficiency control over two university buildings with two total floor area of $18000 \mathrm{~m}^{2}$. The EESC performs an operative control over the engineering systems, the data analysis, the verification of engineering and technology solutions as well as of the software for the automated systems of control over buildings.

The EESC is an experimental site for a new approach in construction: the consideration of a construction project within the whole period of its life cycle: from the moment of erection to the time of its utilization. This approach suggests both the development of the concept and the design of construction projects with consideration of conditions of their further maintenance. Here it is possible to achieve a considerable saving in maintenance cost (cost of resources, services, possible repair works and works in hazardous situations) [9].

Therefore, the aforesaid examples are only single instances and do not contribute much to the development of energy-efficient construction.

The problem lies in the gap between the practice of the use of new construction materials and engineering equipment systems in buildings and the evolution of efficiency and even expediency of their use.

Here the most problematic are the facts that we do not have home-produced energyefficient equipment and the energy-efficient engineering systems are rather expensive.

\section{Conclusions}

Today, city's sustainable development is an actual important task, which is to maintain the balance of city's development and the acceptable level of the environment.

Sustainable development of cities involves the creation of beautiful, healthy, energyefficient city, ensuring full satisfaction of the population's needs.

Now the energy-efficient buildings require considerable additional investments in comparison with traditional buildings. The first stage of the process of improvement of energy efficiency are the heat-carrier regulation systems; it is necessary to install these systems in existing buildings, the pay-back period equals 5 to 6 years.

It is possible to use in Russia other measures and instruments which are successfully applied in energy-efficient buildings abroad.

It should be noted that in European countries the warmth-keeping layer may be made only 15 to $20 \mathrm{~cm}$ thick, while in Russia this layer should be made about $20-30 \mathrm{~cm}$ thick, the walls become thicker and the total floor area becomes less. So it is expedient to develop new construction materials, which are efficient, cheap and durable.

In addition to that, more attention should be paid to the problems of energy efficiency control over the construction projects during their life-cycle. 


\section{References}

1. L.A. Shilov, A.O. Adamtsevich, L.A. Shilova, IRR, 5 (147), 27-31 (2015)

2. I.V. Kryaklina, E.V. Sheshunova, I.L. Grek, E, 1 (2014)

3. N.V. Grinkrug, S.A. Kostrikov, IJABR, 5-3, 389-394 (2015)

4. I.M. Mukhutdinov, A.G. Orlov, V.V. Kondrashin, MNIZH, 5-1 (12), 84 (2013)

5. Information source: http://www.c-o-k.ru/review/samye-izvestnye-v-mireenergoeffektivnye-zdaniya

6. M. Endhardt, E, 5, 20-24 (2010)

7. Information source: http://greenevolution.ru/2014/05/15/samoe-energoeffektivnoezdanie-v-mire

8. A.A. Nechepurenko, E, 3 (34), 48-50 (2014)

9. A.A. Volkov, P.D. Chelyshkov, A.V. Sedov, VE, 5 (2015) 